\title{
Keywords
}

extracellular matrix (ECM); angiogenesis; nociception; fibrosis; skeletal muscle; myocardium

\begin{abstract}
In a growing tissue, the composition of the extracellular matrix (ECM) and its organization are critical for supporting and guiding the assembly of cellular structures and for regulating cellular processes and responses. The growth and re-organization of tissues are essential for development of the embryo; but, in the adult organism, the fetal growth programs can become re-activated in response to injury (1) or in carcinogenesis $(2,3)$. The activation of fetal programs requires intracellular signaling in response to low oxygen and/or low nutrients in the environment, activation of transcription of specific genes regulating tissue remodeling, and synthesis and secretion of ECM proteins. One of the ECM proteins actively produced in the developing embryo and in remodeling adult tissues is thrombospondin- 4 (TSP-4), a member of thrombospondin (TSP) protein family consisting of 5 distinct
\end{abstract}

\footnotetext{
Corresponding author: Olga Stenina-Adognravi, Ph.D., Staff (Professor), Department of Molecular Cardiology, Cleveland Clinic, Lerner College of Medicine/CWRU, Taussig Cancer Center, 9500 Euclid Ave, Cleveland, OH 44195, tel: (216) 444-9057, fax: (216) 445-8204, stenino@ccf.org.

Publisher's Disclaimer: This is a PDF file of an unedited manuscript that has been accepted for publication. As a service to our customers we are providing this early version of the manuscript. The manuscript will undergo copyediting, typesetting, and review of the resulting proof before it is published in its final citable form. Please note that during the production process errors may be discovered which could affect the content, and all legal disclaimers that apply to the journal pertain.
} 
homologous proteins that are products of distinct genes on different chromosomes. Despite the high homology in amino acid sequences of the C-terminal halves of all TSPs $(4,5)$, distinct functions have been ascribed to each member of the family. In particular, TSP-4 has assigned a number of remarkable functions that distinguishes it from other TSPs, and, in several cases, these functions counterbalance contributions of other family members. As a striking example, TSP-1 and TSP-2, which were discovered first and were the focus of many early studies (5-14), are renown for their potent anti-angiogenic effects $(6,9-11,15)$, whereas TSP-4 promotes angiogenesis, and its expression is associated with enhanced vascularization of tissue (16-18). As another example, TSP-1 promotes fibrosis by activating TGF-beta (19-23), and higher levels of TSP-1 have been associated with accelerated fibrosis in several organs $(22,24-29)$, whereas TSP-4 suppresses production of ECM by fibroblasts in cell culture $(18,30)$ and mouse models $(18,31)$. Currently, it is unclear what cellular and molecular processes activated by TSP-4 result in its distinction from other TSPs.

The high expression of TSP-4 in injured tissues and the phenotype of TSP-4 knockout mice suggest that this matricellular protein is a key regulator of tissue growth and remodeling. With the emergence of evidence distinguishing TSP-4 from other TSP family members, we felt that a review focused on TSP-4 was timely and appropriate.

\section{Structure of TSP-4}

TSP-4 (THBS4) is a member of subgroup B of TSPs, which encompasses TSP3, TSP-4 and TSP-5. Each of the three group member is a pentameter; generally, they are homopentamers comprised of a single TSP-3, TSP-4 TSP-5 subunit although heteropentamers involving TSP-4 and TSP-5 have been reported (32). Subgroup A THBSs (THBS-1, TSP-1 and THBS-2, TSP-2) form trimers. The subunits of subgroup A are larger than those of subgroup $\mathrm{B}$ members, a difference arising from the presence of a distinct $\mathrm{N}$-terminal domain followed by a von Willebrand factor Type $\mathrm{C}$ domain. A schematic model depicting the domain organization of the TSP-4 is shown in Fig.1A. Based on its mRNA sequence, the TSP-4 subunit is predicted to have a molecular weight of $\sim 103 \mathrm{~K}$; however, glycosylation raises its molecular weight to $\sim 120 \mathrm{~K}$, still considerably smaller that the subunit of TSP-1, $\sim 145 \mathrm{~K}$. TSP-4 lacks the distinctive features of the N-terminal domain found in the two subgroup A members. The N-terminal domain of TSP-4 and other subgroup B members is followed by a coiled coil region that harbors the oligimerization site, in which the 5 subunits become disulfide linked (Fig.1B). In subgroup B, multiple Type 2 EGF-like domains (TSP-4 has four of these EGF-like repeats), are followed by a series of Type 3 calcium-binding repeats, also referred to a "calcium-binding wire module" by Mosher and colleagues (33-38). These are then followed by the C-terminal "signature" domain, which defines the TSP family. The Cterminal signature domain are highly conserved (53-82\%) across both the subgroup A and group B members.

The oligimerization of the subunits to form the TSP-4 pentamer is shown in Fig. 1B. Calcium plays an important role in maintaining the tertiary structures of all the TSPs, including TSP-4; removal of calcium affects the overall conformation of TSP-4 $(39,40)$. Even though the signature domains are highly homologous, differences in the effects of calcium binding to the signature domains of TSP-4 and TSP-2 were noted (39). A single 
nucleotide polymorphism (SNP) in TSP-4, a proline at position 387 compared to alanine in the predominant form of TSP-4, has been associated with cardiovascular diseases (41-48).

This SNP resides in the third EGF-like repeat and enhances its calcium binding affinity (40).

\section{TSP-4 receptors}

Multiple TSP-4 receptors have been identified, primarily using antibody blocking or small molecule blocking approaches. Among the TSP-4 receptors identified using these strategies are several integrins that support cell adhesion and/or migration on TSP-4 containing substratum. The involvement of specific integrins in recognition of TSP-4 depends on cellular context. On leukocytes, both monocytes and neutrophils, integrins a M $\beta 2$ (Mac-1, $\mathrm{CD} 11 \mathrm{~b} / 18)$ and $\operatorname{av} \beta 3$, have been implicated as TSP-4 receptors $(49,50)$. The involvement of aM $\beta 2$ in TSP-4 recognition was corroborated using cells derived from mice deficient in this leukocyte integrin. Recognition of TSP-4 by aM $\beta 2$ depends upon engagement of the I domain of the integrin with the EGF-like repeats of TSP-4, and this interaction activates intracellular signaling events in leukocytes. Vascular cells, endothelial cells and smooth muscles cells, express av $\beta 3$ although the participation of this integrin in endothelial cell adhesion to and migration on TSP-4 may be different (17). Another integrin with a ligand specificity very similar to av $\beta 3$, av $\beta 5$, has not been directly implicated in TSP-4 recognition. Also, integrin $\alpha 2 \beta 1$ was implicated in endothelial cell migration on TSP-4 using an a 2-specific antibody (17). A non-integrin channels (17, 51-54). Gabapentin is a ligand for $a_{2} \delta-1$ and blocks the binding of TSP-4 to $a_{2} \delta-1 . a_{2} \delta-1$ also reacts with subgroup A TSPs in immunoprecipitation assays from cerebral cortex tissues. These interactions involve the EGF-like repeats of the TSPs.

\section{TSP-4 expression in embryonic development and adult organisms}

TSP-4 or its orthologs are present in lower organisms starting with Basal metazoa (55), unlike TSP-1 and TSP-2 that appear later in evolution during the development of a vascular system (55). In Xenopus, TSP-4 is expressed in the developing embryo starting with neurulation stage (56). In adult human tissues, the highest expression of TSP-4 is detected in hearts and skeletal muscles (57). It was noted by Tucker et al (34) that the pattern of expression of the TSP-4 transcript was clearly different from the patterns of expression of other TSPs.

\section{Expression of TSP-4 in the osteogenic tissues}

In chick embryo, TSP-4 was found in osteogenic tissues in the mesenchyme surrounding the bone anlage during the initial stages of osteogenesis, but the TSP-4 mRNA disappeared at later stages (58). In the same study, TSP-4 mRNA was detected in the eye of chick embryos, where it was associated with later ossified structures, and in corneal fibroblasts beneath the corneal epithelium (58). TSP-4 was also detected in myotendinous junctions of the extraocular muscle of zebrafish (59) and in the basement membrane zone of human ocular surface epithelia, a specialized microenvironment in which maintenance, self-renewal, activation, and proliferation of stem cells by external signals occurs (60). 


\section{Expression of TSP-4 in the tendon}

TSP-4 is abundant in the tendon (61-64) and is accepted as one of the markers of mature tenocytes (65). In tendon, TSP-4 is associated with fibrillar structures that also contain TSP-5 and have a different direction than TSP-3-containing fibers (30). TSP-4 in tendon does not co-localize with TSP-3, but the staining for TSP-4 and TSP-5 largely overlap (30). Analysis of TSP-4 from equine tendon revealed that TSP-4 and TSP-5 monomers assemble into heteropentamers that cannot be separated under non-reducing conditions (32). The significance of heteropentamers remains unclear. There were no obvious signs of compensation in the tendon of TSP-4 KO mouse: the levels of TSP-3 and TSP-5 did not change with the knockout of TSP-4 suggesting a distinct function and regulation for TSP-4 in tendon.

In Drosophila, there is only one TSP that has the structural features of group B thrombospondins (TSP-3, TSP-4, and TSP-5 in humans). Drosophila's TSP-4 ortholog was found to be highly expressed in tendon progenitors (66).

\section{Expression of TSP-4 in the skeletal muscle}

In Drosophila and zebrafish, the TSP-4 ortholog is necessary for the formation of myotendinous junctions, and without it, the muscles detach upon contraction (67). Injections of human TSP-4 into zebrafish restored the function of muscles and revealed that TSP-4 provides a scaffold for a proper ECM assembly in myotendinous junctions and supports intracellular signaling.

In axolotl, the ortholog of TSP-4 is highly expressed during limb regeneration, and the patterns of expression overlap with the expression pattern during larval limb development (68).

\section{Expression of TSP-4 in the nervous system}

The role of TSP-4 in skeletal muscle is not limited to maintaining the structure and function of myotendinous junctions; it is influential everywhere where the muscle connects to another tissue. TSP-4 is expressed in neuromuscular junctions, likely by the muscle interstitial cells, and its expression increases dramatically after denervation of a muscle (69). In this location, TSP-4 incorporates into ECM and promotes the outgrowth of neurites after denervation. These functions of TSP-4 are strikingly distinct from the functions of other TSPs. High levels of TSP-4 but not other TSPs, were found in a wide range of neurons and were associated with synapse-rich layers in the adult nervous system (69).

\section{Expression of TSP-4 in the eye}

Expression of TSP-4 was detected in embryonic mouse retina at day 15 (70). In the adult mouse eye, TSP-4 was detected in ganglion cell layer, the inner nuclear layer, the plexiform layers, and in the sclera (70). In the adult bovine eye, TSP-4 was expressed in multiple eye structures: cornea, conjunctiva, aqueous ducts, sclera, iris, ciliary processes and muscle, trabecular meshwork, Bruch's membrane, retina, lamina cribrosa, optic nerve, and blood vessel wall (71). Cultured retinal pigment epithelial cells (RPE) express TSP-4 together with three other TSP family members, TSP1, 2, and 3 (72). 


\section{Expression of TSP-4 in the vasculature and the heart}

TSP-4 is produced in the vascular wall by endothelial cells (EC) and smooth muscle cells (SMC) (73) and normally localizes either on the outer side of capillaries or in the adventitia of larger blood vessel $(30,49)$.

In myocardium, the highest expression was seen in the fibrous skeleton of the heart, which provides structure, tensile strength, and stiffness to the myocardium (29). The protein was also present in perimysium between bundles of cardiomyocytes and in the endomysium, the extracellular space between cardiomyocytes. TSP-4 was also consistently present in blood vessels of various sizes in the heart, in the adventitia of larger vessels and in the subendothelial matrix of capillaries.

The expression of TSP-4 is tightly regulated, similarly to the expression of other TSPs, but the unique spatial and temporal patterns suggest that it performs functions distinct from other TSPs (74).

\section{TSP-4 expression in pathology}

During the development of an atherosclerotic lesion, TSP-4 was found in the lesion in the Tunica Intima where it contributed to the inflammatory atherosclerotic process (49).

Consistent with the production of TSP-4 in the blood vessel wall, a high TSP-4 expression is detected in cancers, where the growth of the tumor relies critically on the vasculature. TSP-4 was in top $1 \%$ of most upregulated genes in several types of cancer: e.g., gastric cancer (7577), and especially in breast cancer (78-80).

Perhaps the most striking increase in TSP-4 expression levels was detected in remodeling hypertrophic and failing hearts, both human and murine $(18,31,81)$, suggesting its important role in the remodeling of the myocardium in response to the pressure overload.

\section{Role of TSP-4 in the connective tissue}

The expression patterns of TSP-4 in axolotl during the limb regeneration and larval limb development suggests the involvement of TSP-4 in ECM remodeling and formation of "transitional matrix" (68). In higher organisms that have lost the ability to regenerate limbs, TSP-4 participates in wound healing and scar formation.

Similar to other TSPs, TSP-4 regulates the production and assembly of collagen and organization, repair, and remodeling of ECM. J. Adams proposed that the conserved L-lectin domain of all TSPs serves to flexibly associate TSPs with ECM to regulate the interstitial ECM of various tissues (82). TSP-1, TSP-2, or TSP-4 deficiency all result in the formation of disorganized collagen fibrils and increased number of fibrils of larger diameter $(30,82$ 84). In addition to this organizational role, TSP-1 and TSP- 2 knockouts altered the shape of the fibrils. While TSP-4 deficiency did not result in shape change, it caused increased spacing between fibrils. Although the original concept of matricellular proteins suggested that they are not structural proteins and may only affect the fibrillogenesis by regulating the functions of fibroblasts, TSP-4 may also function as a structural protein: it is very abundant 
in the tendon $(32,61,62)$ and presents as a well-organized fibrillar network (30). TSP-4 binds to collagens I, II, III, and V, and non-collagenous proteins are found in close proximity to TSP-4 in ECM, e.g., laminin-1, fibronectin, matrilin-2, but not to collagen IV (85). TSP-4 binds most ECM protein ligands independently of the $\mathrm{N}$-terminal and coil-coiled domain, and the interactions are regulated by divalent cations, with binding to collagens induced by $\mathrm{Zn}^{2+}(85)$. The complex multiple strong interactions of TSP-4 with ECM proteins suggest a role as an adaptor protein in extracellular matrix assembly (85). The $\mathrm{N}$-terminal heparinbinding domain is thought to bind the cell surface, and this binding may account for the high TSP-4 immunoreactivity in the pericellular compartment with close association to the cell surface in the tendon (86) (Fig.1C).

The production of TSP-4 is regulated by the properties of the ECM. Mesenchymal stem cells (MSC) produced 2.5-fold more TSP-4 when grown on highly anisotropic matrices than the cells on low anisotropy matrices (87), reflecting the tenogenic differentiation of MSC that also produced high levels of collagen I and III. TSP-4 upregulation seems to be always associated with the formation of tendon tissue: treatment of the murine mesenchymal stem cell line with BMP12 and BMP13 that induce formation of the tendon-like tissue (versus osteogenic differentiation in response to BMP2) resulted in a dose-dependent TSP-4 upregulation (88).

TSP-4 appears to play a role in wound healing and hypertrophic scar formation. It was one of the 6 genes selectively upregulated in hypertrophic scars, along with collagen I (89). Excisional wound healing was significantly delayed in $T h b s 4^{-/}$mice, with decreased angiogenesis (17).

\section{Regulation of ECM by TSP-4}

The effects of TSP-4 on the production of ECM are tissue-specific. For example, in the heart, TSP-4 deficiency augmented deposition of ECM (18), while in the skeletal muscle TSP-4 knockout was associated with the loss of ECM (30). Consistent with these observations in Thbs $4^{-/}$mice, rTSP-4 administration increased production of collagens by cultured fibroblasts (18), but treatment of cultured EC with rTSP-4 resulted in a loss of specific ECM components (30).

TSP-4 controls modifications of heparan sulfates (HS) chains the levels of HS core proteins the levels of HS core proteins in skeletal muscle tissue and (30). Glypican and beta-glycan, a receptor for TGF-beta, were remarkably downregulated in the skeletal muscle tissue of Thbs $4^{-/}$mice (30). In cultured endothelial cells (EC), TSP-4 induced the production of beta-glycan and increased TGF-beta signaling. TSP-4 appears to regulate the production of HS core proteins by influencing their expression rather than their retention in tissues: the levels of two enzymes responsible for the key steps in synthesis of HS, heparan sulfate 2-Osulfotransferase 1 and N-heparan sulfate sulfotransferase 3, were reduced in $T h b s 4^{-/}$mice, and cultured EC had increased levels of these enzymes in response to rTSP-4 (30).

In the skeletal myofibers, TSP-4 enhances vesicular trafficking of dystrophin-glycoprotein and integrin attachment complexes to stabilize the sarcolemma (90). Interestingly, in a 
Drosophila model of muscular dystrophy, muscle-specific overexpression of either Drosophila TSP-4 ortholog or mouse TSP-4 rescued the phenotype, stressing the structural and functional evolutionary conservation of TSP-4 (90).

Expression of TSP-4 appears to be closely associated with TGF-beta signaling $(16,30,91)$. However, the associations are complex and point to a multi-stage reciprocal regulation between TGF-beta and TSP-4. In addition to the loss of beta-glycan in skeletal muscle of Thbs $4^{-/}$mice and EC from these mice, the effect of TSP-4 on TGF-beta signaling was augmented in Thbs $4^{-/-}$EC, where beta-glycan was absent, suggesting that beta-glycan played an inhibitory role and that TSP-4 regulates both the initiation of TGF-beta signaling and its feedback inhibition. TSP-4 was upregulated in response to TGF-beta in cultured EC, in vivo (16), and other cell types (unpublished data), but higher levels of TSP-4 were detected in the ventricular cardiomyocytes of TGF-deficient mice (91). Although the signaling pathways connecting TSP-4 and TGF-beta are not completely understood, it is clear that TSP-4 is regulated by these pathways and is in turn affecting TGF-beta signaling.

\section{TSP-4 in skeletal muscle}

High levels of TSP-4 in myotendinous and neuromuscular junctions suggest that it is important for the correct assembly and function of the motor unit. Indeed, without TSP-4 skeletal muscle does not function properly. Both the Drosophila and the zebrafish TSP-4 orthologs are required for the assembly of the myotendinous junctions and their repair after injury $(67,92)$. The protein interacted with the integrins and organized a proper laminin localization to promote attachment, and both muscle and tendon TSP-4 was required for attachment. The pentameric structure of TSP-4 was essential for these scaffolding functions, confirming its scaffolding function and simultaneous binding to multiple ligands and receptors as is schematically demonstrated in Figure 1C. In zebrafish, TSP-4 was a component of extraocular tendon at muscle origins (59).

Although the phenotype in mice is less striking, TSP-4 knockout in mice still results in lower muscle mass and poorer performance of limbs. Compared to WT mice, Thbs $4^{-/}$mice are less capable of maintaining grip strength with age, thereby implying possible impairment of muscle function (30). By stabilizing the membrane and cellular attachment in skeletal muscle, TSP-4 regulates the skeletal muscle integrity (90). Loss of TSP-4 gene resulted in spontaneous dystrophic changes in skeletal muscle with aging and accelerated muscular dystrophy in mouse models, and overexpression of TSP-4 mitigated the dystrophic disease (90).

Although TSP-4 seems to have some structural role in the tendon, in skeletal muscle it appears to function as a classical matricellular protein, regulating the composition of ECM and affecting the cellular functions of myocytes. There, TSP-4 is associated with myotendinous junctions, perimysium, endomysium, and endothelial cells (EC) (30). In the cell culture, the C-terminal fragment of TSP-4 promoted myoblast adhesion although it was not as potent as a similar fragment of TSP-1, despite very high homology between TSPs in this region (93). In vivo, TSP-4 regulates the production and composition of ECM in skeletal muscle and the cellular metabolic functions. TSP-4 is especially abundant in red muscles 
that primarily utilize oxidative metabolism. TSP-4 deficiency results in impaired metabolism in red muscles: the uptake of very low-density lipoproteins (VLDL) was decreased in red muscles of $T h b s^{-1-}$ mice and in cultured EC from these mice (30). While the activity of lipoprotein lipase, the enzyme regulating the uptake of VLDL, was decreased both in vivo and in vitro, TSP-4 did not affect the levels of lipoprotein lipase. It appears that the regulation of HS proteoglycans influenced the activity of lipoprotein lipase that has to bind the surface of a cell to become active. Thus, TSP-4 maintains the LPL activity and the metabolism of red muscle by supporting production and modification of specific HS. Thbs $4^{-/}$mice on the high fat/high carbohydrate content diet developed higher blood levels of total cholesterol and VLDL, consistent with the inability to process VLDL due to the impaired function of endothelial LPL (30).

\section{Functions of TSP-4 in myocardium}

Healthy and especially remodeling hearts express high levels of TSP-4 (18, 31, 81, 94, 95). Studies in $\mathrm{Thbs}^{-1-}$ mice revealed the importance of TSP-4 in heart remodeling and maintenance of a healthy heart ECM $(18,31)$. In response to pressure overload, Thbs $4^{-/}$ mice developed a significantly higher heart weight to body weight ratio than WT mice, and function of the heart was impaired. Control of fibrosis caused by pressure overload is the main function of TSP-4 in remodeling heart. TSP-4 does not affect the size or apoptosis of cardiomyocytes, but prevents deposition of interstitial ECM and heart hypertrophy and maintains the adaptive mechanisms that augment contractility and activate stretch-response upon pressure overload. TSP-4 prevents depositions of collagen I, II, III, and V, without affecting the levels of collagen IV (30). The increased levels of TSP-4 mRNA in remodeling hearts were associated with interstitial fibroblasts (30). Interestingly, ECM deposition increases in aging mice without pressure overload (18), suggesting that TSP-4 becomes more influential with age, consistent with the observation of age-related changes in skeletal muscle of aged mice (30). One of the signals upregulating TSP-4 in angiotensin II infusion model of cardiac hypertrophy is Kruppel-like factor 6 (Klf6) (96): in $\mathrm{Klf6}^{+/-}$mice (Klf6 ${ }^{-1-}$ is embryonically lethal), diminished cardiac fibrosis was associated with increased expression of TSP-4. Chromatin precipitation showed recruitment of Klf6 to TSP-4 promoter and a dose-dependent repression of TSP-4 promoter activity by Klf6. The loss of the contractility and stress-response adaptation was associated with changes in the composition of the matrix and direct regulation by TSP-4 in response to pressure overload: incubation of the muscle with recombinant TSP-4 restored the contractility, suggesting that TSP4 is a myocyte-interstitial mechano-signaling protein regulating adaptive cardiac contractile responses to acute stress (31).

Similar to other tissues, in the myocardium, TSP-4 is upregulated in many situations involving injury and tissue remodeling. Increased expression of TSP-4 was detected in the chronic ischemic myocardium of non-failing human left ventricle and was associated with chronic myocardium remodeling and expression of a number of other ECM genes involved in matrix remodeling (97).

A surprising intracellular function for TSP-4 in cardiomyocytes was associated with its functions in secretory pathways. The type- 3 repeat domain of TSP-4 bound the ER luminal 
domain of activating transcription factor $6 a$ (Atf6a) to promote its nuclear shuttling and to activate the protective ER stress response (95). This function is shared by other TSPs and is not limited to cardiomyocytes: TSP-4 activated of the ER stress response in skeletal myocytes as well (95). In addition to activation of the ER stress response, TSPs, including TSP-4, were found to affect cellular calcium signaling through an interaction with STIM1, a transmembrane protein that functions in the endoplasmic reticulum (ER) to detect calcium depletion, in the ER and plasma membrane (98). These novel functions for TSP-4 in ER open a whole new direction of study of TSP-4 and other TSPs - their intracellular regulatory roles associated with secretory pathways that have not been appreciated earlier. Not only protein interactions can occur in the ER environment before proteins are secreted, but important signaling events can be initiated by TSP-4 and other secreted proteins while progressing through the secretory pathways.

Interestingly, the binding site that mediated the interaction of TSP-4 to Atf6a was localized to Type 3 repeats of TSP-4, the same region where SNP associated with increased risk of the myocardial infarction (MI) and the coronary artery disease (CAD) was found (44) and confirmed in several human population studies (41-48). This region of TSP-4 appears to be important in most of TSP-4 functions, and the mutation corresponding to the diseaseassociated SNP results in a change of TSP-4 properties and its interactions with the cells (4, $17,40,50,73,99)$.

\section{TSP-4 in remodeling of vasculature}

TSP-4 may affect the development of MI/CAD in several complementary ways: by regulating the adaptive responses of the myocardium, by influencing the growth and remodeling of the blood vessels, and by affecting the inflammatory responses. Atherosclerotic lesions in $T h b s 4^{-/-} / A p o E^{-/-}$mice were smaller and less cellular, with decreased levels of inflammatory markers and EC activation in blood vessels (49). TSP-4 was abundant in atherosclerotic lesions and areas of blood vessels prone to development of lesions, and TSP-4 deficiency prevented accumulation of macrophages in lesions. rTSP-4 supported migration and adhesion of macrophages and neutrophils and activation of proinflammatory signaling in leukocytes $(49,50)$. These observations assigned another important role for TSP-4 in tissue remodeling - regulation of local inflammation through the effects on leukocytes.

Inflammation and tissue remodeling are intimately associated with angiogenesis and remodeling of the vasculature. The first indication that TSP-4 may regulate these processes came from a study of remodeling myocardium in response to the pressure overload: in Thbs $4^{-1-}$ mice, the area occupied by microvessels was dramatically decreased after transverse aortic constriction (TAC) as compared to WT mice (30). When the ability of TSP-4 to support angiogenesis was tested directly in vivo in mouse models of angiogenesis and in vitro, TSP-4 was found to promote the growth of new blood vessels and to support the pro-angiogenic functions of EC (17). In developing retina, in cancer and Matrigel plug models, and in wound healing, TSP-4 knockout mice had delayed angiogenic response, while the mutant MI/CAD-promoting TSP-4 was even more pro-angiogenic than WT TSP-4. 
The pro-angiogenic properties of TSP-4 set this TSP apart from other TSPs: TSP-1 and TSP-2 are two well-known, potent inhibitors of angiogenesis while TSP-3 did not affect angiogenesis (100), and no angiogenesis-related effects were reported for TSP-5. TSP-3, TSP-4, and TSP-5 do not harbor the protein domains that mediate the anti-angiogenic activities of TSP-1 and TSP-2 $(5,7)$. More intriguing is the difference between TSP-4 and TSP-3/TSP-5 that have a very high homology to each other.

Based on the increased pro-angiogenic properties of TSP-4 with the mutation in type 3 repeat region and the dependence of pro-angiogenic effects on a $2 \delta-1$ receptor for gabapentin that was shown to interact with this region of TSPs $(17,52)$, the third EGF-like repeat is critical for the pro-angiogenic functions of TSP-4.

\section{TSP-4 and TGF-beta}

TSP-1 activates TGF-beta $(20-23,101,102)$ and is regulated by TGF-beta $(16,103,104)$. It is not surprising that TSP-4, a regulator of ECM remodeling and synthesis, is also involved in responses mediated by TGF-beta, the main regulator of ECM production.

TSP-4 was required for angiogenesis in response to TGF-beta: in Thbs $4^{-/}$mice or in models where TSP-4 production was suppressed using shRNA, the angiogenic response to TGF-beta was dramatically reduced, and the growth of a tumor caused by TGF-beta was completely lost (16). TGF-beta induced production of TSP-4 but not other TSPs in EC. More than one report showed that this response to TGF-beta is cell-type-specific. TSP-4 was not detected in response to TGF-beta in vascular smooth muscle cells in vitro (16), and the myocyte-selective TGF $\beta$ inhibition augmented the synthesis of TSP-4 in myocytes.

The cell-specificity of the production of TSP-4 in response to TGF-beta suggests that TSP-4 may mediate stage-specific effects of TGF-beta, i.e., acceleration of tumor growth at the later stages when a tumor is well vascularized, and ECs provide sufficient amounts of TSP-4 to support further angiogenesis. Although the details of the regulation of TSP-4 production in response to TGF-beta are not fully known, the involvement of SMAD3 was reported (16).

\section{TSP-4 in cancer}

The pro-angiogenic properties of TSP-4 may explain its high expression in several cancers. Increased expression of TSP-4 in cancer tissues is associated with cancer progression. Remarkably, TSP-4 has been identified among the top 1\% of most upregulated genes in several types of cancer (75-80). In breast cancer, increased TSP-4 expression was associated with the stromal response to invasive cancer, suggesting that TSP-4 in ECM contributes to the tumor progression and facilitates the invasion of tumor cells (105). Differential expression of TSP-4 was detected in lobular versus ductal breast carcinomas (106), suggesting that it could be a marker of a specific breast cancer type, and studying its effect could be important to understand the basis of phenotyping differences in breast cancers. TSP-4 also showed the strongest correlation to a histological type of gastric adenocarcinoma, being overexpressed in diffuse type versus intestinal type (107). These associations with specific forms of cancers versus other forms could shed light on TSP-4 functions in cancer growth if further investigated. TSP-4 was upregulated in Wilms tumor 
and mesoblastic nephroma (108) and prostate cancers (109). In hepatocellular carcinoma, TSP-4 was overexpressed and correlated with prognosis (110), and its knockdown inhibited hepatocellular-carcinoma-induced angiogenesis, migration, and invasion of the cancer cells. TSP-4 was identified as one of the members of a gene network, which regulates liver bud expansion by controlling hepatoblast migration and adhesion during the liver development and was proposed as a candidate gene for investigation of liver carcinogenesis (111).

The roles of TSP-4 in different cancers are as complex as the roles of another TSP, TSP-1, widely associated with cancer: both have been reported as promoting certain types of cancers and inhibiting others. TSP-4 gene was methylated and silenced in colon cancer (112, 113 ) and in primary cutaneous T-cell lymphoma (114). Based on these observations, a protective role for TSP-4 was proposed. However, further examination of the TSP-4 role in cancer is warranted to distinguish between the silencing of TSP-4 as a tumor suppressor or its suppression as a feed-back protective anti-cancer mechanism. A direct effect of TSP-4 on cancer cells is also possible, although opposite roles for TSP-4 were found in different cancer cells: forced expression of TSP-4 in colonies of colorectal cancers caused dramatic repression of tumor growth (113), but knockdown of TSP-4 in prostate cancer cells significantly reduced their migratory and invasive abilities and decreased the expression levels of p38 and matrix metalloproteinase (MMP)-9 (109). As with TSP-1, effects of TSP-4 in cancerare complex and suggest tissue specific and cell specific roles.

\section{Role of TSP-4 in the nervous system}

Important and unexpected functions have been recently ascribed to TSP-4 in the nervous system.

Over twenty years ago, Arber and Caroni reported that TSP-4 is expressed by neurons, promotes neurite outgrowth, and is especially abundant in synapse-rich structures in the cerebellum and retina of adults (69). These unanticipated observations were made during the search for muscle genes that may be involved in neuromuscular signaling. TSP-4 was tested for effects on cultured motor, sensory, and retina neurons, and the results suggested that TSP-4 was a preferred substrate and promoted neurite outgrowth. The effect of TSP-4 is dependent on laminin, and TSP-4 acts as an organizer of adhesive and axon outgrowthpromoting molecule in the ECM (70). TSPs were identified as a necessary and sufficient synaptogenic signal secreted by astrocytes that increases synapse number $(115,116)$.

The CNS synaptogenesis was dependent on interaction of a $2 \delta-1$ gabapentin receptor with Type 3 (EGF-like repeats) domains of TSPs (52). TSP-4 promoted neuronal differentiation of neural progenitors that may be a potential source of therapy for neurological disorders (117). The idea that TSP-4 may be involved in signaling during development and repair processes in nervous system was further tested in other models. A localized photothrombotic/ischaemic cortical injury initiated a marked increase in astrocyte production of TSP-4 from the postnatal subventricular zone, where the neural stem cells express a remarkably high level of TSP-4 (118). In Thbs $4^{-/-}$mice, migration of newly formed neurons along the rostral migratory stream (RMS) to eventually integrate the olfactory bulb neuronal circuitry was impaired: some neurons migrated out of RMS (119), 
supporting the role for astrocyte-produced TSP-4 in the migration of newly formed neurons to the olfactory bulb. The robust post-injury astrogenic response was modulated by TSP-4 via direct Notch1 receptor binding and activated downstream signals for glia production. Thbs $4^{-/}$mice had severe defects in cortical-injury-induced SVZ astrogenesis and abnormal glial scar formation in response to injury, as well as increased hemorrhage. These results implicate TSP-4 into the post-injury recruitment of neural stem cells (118). After a subtle trauma of the brain, increased expression of TSP-4 was detected in the hippocampal tissue at the injured side and the contralesional side, implicating TSP-4 in reparative response involving activation of astrocytes and triggering molecular and structural changes in the uninjured hemisphere (120).

Binding of TSP-4 to a receptor for an anti-epileptic and analgesic drug gabapentin (52) and its high expression upon injury suggested a role for TSP-4 in pain development after injury. In a neuropathic pain model of spinal nerve ligation injury, increased expression of TSP-4 was demonstrated at the injury side of dorsal spinal cord that correlates with the development of neuropathic pain states. Blockade of TSP-4 or inactivation of Thbs 4 gene prevented hypersensitivity, while injections of TSP-4 caused hypersensitivity and increased the frequency of excitatory postsynaptic potential (121). The effect of TSP-4 was due to decreasing high-voltage-activated calcium current and increasing low-voltage-activated calcium current in dorsal root ganglia (DRG) (53) by activating its receptor a $2 \delta-1$ calcium channel subunit (54). Further investigation of this new function of TSP-4 in various models $(51,122,123)$ suggested that TSP-4 could become a potential target for development of antagonists with therapeutic potential for target-specific neuropathic pain management.

\title{
Concluding Remarks
}

TSP-4 was first identified in 1993 (57) but interest in the molecule was modest for the remainder of the twentieth century. Now there are over 140 publications related to TPS- 4 in PubMed. These reports identify numerous unanticipated functions of TSP-4, often found in gene expression profiles, in many different tissues and in various physiological and pathological responses. We can anticipate that the exponential increase in interest in TSP-4 will continue and may even explore TSP-4 as a therapeutic target to encourage angiogenesis under ischemic conditions, to suppress tumor growth in various tissues, and to alleviate pain.

\section{Acknowledgments}

Funding

This work was supported by the National Institutes of Health [grant numbers HL117216 and CA177771]

\author{
Abbreviations \\ Atf6a activating transcription factor 6a \\ ApoE apolipoprotein E \\ BMP bone morphogenic protein \\ CAD coronary artery disease
}




\begin{tabular}{|c|c|}
\hline CNS & central nervous system \\
\hline DRG & dorsal root ganglia \\
\hline $\mathbf{E C}$ & endothelial cells \\
\hline EGF & epithelial growth factor \\
\hline ECM & extracellular matrix \\
\hline $\mathbf{E R}$ & endoplasmic reticulum \\
\hline HS & heparin sulfate \\
\hline Klf6 & Kruppel-like factor 6 \\
\hline KO & knockout \\
\hline MI & myocardial infarction \\
\hline MMP & matrix metalloproteinase \\
\hline MSC & mesenchymal stem cells \\
\hline RMS & rostral migratory stream \\
\hline shRNA & small hairpin RNA \\
\hline SMAD3 & Mothers against decapentaplegic homolog 3 \\
\hline SMC & smooth muscle cells \\
\hline SNP & single nucleotide polymorphism \\
\hline STIM1 & Stromal interaction molecule 1 \\
\hline SVZ & subventricular zone \\
\hline TAC & transverse aortic constriction \\
\hline Thbs4 & mouse TSP-4 gene \\
\hline TGF & transforming growth factor \\
\hline TSP & thrombospondin \\
\hline VLDL & very low density lipoprotein \\
\hline
\end{tabular}

\section{References}

1. Rajabi M, Kassiotis C, Razeghi P, Taegtmeyer H. 2007; Return to the fetal gene program protects the stressed heart: a strong hypothesis. Heart Fail Rev. 12:331-343. [PubMed: 17516164]

2. Rangel MC, Bertolette D, Castro NP, Klauzinska M, Cuttitta F, Salomon DS. 2016; Developmental signaling pathways regulating mammary stem cells and contributing to the etiology of triplenegative breast cancer. Breast Cancer Res Treat. 156:211-226. [PubMed: 26968398]

Matrix Biol. Author manuscript; available in PMC 2020 January 01. 
3. Kang Y, Massague J. 2004; Epithelial-mesenchymal transitions: twist in development and metastasis. Cell. 118:277-279. [PubMed: 15294153]

4. Stenina OI, Topol EJ, Plow EF. 2007; Thrombospondins, their polymorphisms, and cardiovascular disease. Arterioscler Thromb Vasc Biol. 27:1886-1894. [PubMed: 17569883]

5. Adams JC, Lawler J. 2004; The thrombospondins. Int J Biochem Cell Biol. 36:961-968. [PubMed: 15094109]

6. Lawler PR, Lawler J. 2012; Molecular basis for the regulation of angiogenesis by thrombospondin-1 and -2. Cold Spring Harb Perspect Med. 2:a006627. [PubMed: 22553494]

7. Adams JC, Lawler J. 2011; The thrombospondins. Cold Spring Harb Perspect Biol. 3:a009712. [PubMed: 21875984]

8. Chen H, Herndon ME, Lawler J. 2000; The cell biology of thrombospondin-1. Matrix Biol. 19:597614. [PubMed: 11102749]

9. Lawler J, Detmar M. 2004; Tumor progression: the effects of thrombospondin-1 and -2. Int J Biochem Cell Biol. 36:1038-1045. [PubMed: 15094119]

10. Lawler J. 2002; Thrombospondin-1 as an endogenous inhibitor of angiogenesis and tumor growth. J Cell Mol Med. 6:1-12. [PubMed: 12003665]

11. Lawler J. 2000; The functions of thrombospondin-1 and-2. Curr Opin Cell Biol. 12:634-640. [PubMed: 10978901]

12. Bornstein P. 2001; Thrombospondins as matricellular modulators of cell function. J Clin Invest. 107:929-934. [PubMed: 11306593]

13. Bornstein P, Armstrong LC, Hankenson KD, Kyriakides TR, Yang Z. 2000; Thrombospondin 2, a matricellular protein with diverse functions. Matrix Biol. 19:557-568. [PubMed: 11102746]

14. Armstrong LC, Bornstein P. 2003; Thrombospondins 1 and 2 function as inhibitors of angiogenesis. Matrix Biol. 22:63-71. [PubMed: 12714043]

15. Sargiannidou I, Zhou J, Tuszynski GP. 2001; The role of thrombospondin-1 in tumor progression. Exp Biol Med (Maywood). 226:726-733. [PubMed: 11520937]

16. Muppala S, Xiao R, Krukovets I, Verbovetsky D, Yendamuri R, Habib N, Raman P, Plow E, Stenina-Adognravi O. 2017; Thrombospondin-4 mediates TGF-beta-induced angiogenesis. Oncogene. 36:5189-5198. [PubMed: 28481870]

17. Muppala S, Frolova E, Xiao R, Krukovets I, Yoon S, Hoppe G, Vasanji A, Plow E, SteninaAdognravi O. 2015; Proangiogenic Properties of Thrombospondin-4. Arterioscler Thromb Vasc Biol. 35:1975-1986. [PubMed: 26139464]

18. Frolova EG, Sopko N, Blech L, Popovic ZB, Li J, Vasanji A, Drumm C, Krukovets I, Jain MK, Penn MS, Plow EF, Stenina OI. 2012; Thrombospondin-4 regulates fibrosis and remodeling of the myocardium in response to pressure overload. FASEB J. 26:2363-2373. [PubMed: 22362893]

19. Zhou Y, Poczatek MH, Berecek KH, Murphy-Ullrich JE. 2006; Thrombospondin 1 mediates angiotensin II induction of TGF-beta activation by cardiac and renal cells under both high and low glucose conditions. Biochem Biophys Res Commun. 339:633-641. [PubMed: 16310163]

20. Ribeiro SM, Poczatek M, Schultz-Cherry S, Villain M, Murphy-Ullrich JE. 1999; The activation sequence of thrombospondin-1 interacts with the latency-associated peptide to regulate activation of latent transforming growth factor-beta. J Biol Chem. 274:13586-13593. [PubMed: 10224129]

21. Murphy-Ullrich JE, Poczatek M. 2000; Activation of latent TGF-beta by thrombospondin-1: mechanisms and physiology. Cytokine Growth Factor Rev. 11:59-69. [PubMed: 10708953]

22. Daniel C, Wiede J, Krutzsch HC, Ribeiro SM, Roberts DD, Murphy-Ullrich JE, Hugo C. 2004; Thrombospondin-1 is a major activator of TGF-beta in fibrotic renal disease in the rat in vivo. Kidney Int. 65:459-468. [PubMed: 14717916]

23. Crawford SE, Stellmach V, Murphy-Ullrich JE, Ribeiro SM, Lawler J, Hynes RO, Boivin GP, Bouck N. 1998; Thrombospondin-1 is a major activator of TGF-beta1 in vivo. Cell. 93:1159-1170. [PubMed: 9657149]

24. Belmadani S, Bernal J, Wei CC, Pallero MA, Dell'italia L, Murphy-Ullrich JE, Berecek KH. 2007; A thrombospondin-1 antagonist of transforming growth factor-beta activation blocks cardiomyopathy in rats with diabetes and elevated angiotensin II. Am J Pathol. 171:777-789. [PubMed: 17640965] 
25. Cai H, Yuan Z, Fei Q, Zhao J. 2012; Investigation of thrombospondin-1 and transforming growth factor-beta expression in the heart of aging mice. Exp Ther Med. 3:433-436. [PubMed: 22969907]

26. Kaiser R, Frantz C, Bals R, Wilkens H. 2016; The role of circulating thrombospondin-1 in patients with precapillary pulmonary hypertension. Respir Res. 17:96. [PubMed: 27473366]

27. Smadja DM, Nunes H, Juvin K, Bertil S, Valeyre D, Gaussem P, Israel-Biet D. 2014; Increase in both angiogenic and angiostatic mediators in patients with idiopathic pulmonary fibrosis. Pathol Biol (Paris). 62:391-394. [PubMed: 25239280]

28. Zeisberg M, Tampe B, LeBleu V, Tampe D, Zeisberg EM, Kalluri R. 2014; Thrombospondin-1 deficiency causes a shift from fibroproliferative to inflammatory kidney disease and delays onset of renal failure. Am J Pathol. 184:2687-2698. [PubMed: 25111226]

29. Inoue M, Jiang Y, Barnes RH 2nd, Tokunaga M, Martinez-Santibanez G, Geletka L, Lumeng CN, Buchner DA, Chun TH. 2013; Thrombospondin 1 mediates high-fat diet-induced muscle fibrosis and insulin resistance in male mice. Endocrinology. 154:4548-4559. [PubMed: 24140711]

30. Frolova EG, Drazba J, Krukovets I, Kostenko V, Blech L, Harry C, Vasanji A, Drumm C, Sul P, Jenniskens GJ, Plow EF, Stenina-Adognravi O. 2014; Control of organization and function of muscle and tendon by thrombospondin-4. Matrix Biol. 37:35-48. [PubMed: 24589453]

31. Cingolani OH, Kirk JA, Seo K, Koitabashi N, Lee DI, Ramirez-Correa G, Bedja D, Barth AS, Moens AL, Kass DA. 2011; Thrombospondin-4 is required for stretch-mediated contractility augmentation in cardiac muscle. Circ Res. 109:1410-1414. [PubMed: 22034490]

32. Sodersten F, Ekman S, Schmitz M, Paulsson M, Zaucke F. 2006; Thrombospondin-4 and cartilage oligomeric matrix protein form heterooligomers in equine tendon. Connect Tissue Res. 47:85-91. [PubMed: 16754514]

33. Carlson CB, Bernstein DA, Annis DS, Misenheimer TM, Hannah BL, Mosher DF, Keck JL. 2005; Structure of the calcium-rich signature domain of human thrombospondin-2. Nat Struct Mol Biol. 12:910-914. [PubMed: 16186819]

34. Liu Y, Mosher DF. 2009; Interactions among stalk modules of thrombospondin-1. J Biol Chem. 284:28563-28570. [PubMed: 19706610]

35. Carlson CB, Liu Y, Keck JL, Mosher DF. 2008; Influences of the N700S thrombospondin-1 polymorphism on protein structure and stability. J Biol Chem. 283:20069-20076. [PubMed: 18499674]

36. Carlson CB, Gunderson KA, Mosher DF. 2008; Mutations targeting intermodular interfaces or calcium binding destabilize the thrombospondin-2 signature domain. J Biol Chem. 283:2708927099. [PubMed: 18682400]

37. Annis DS, Murphy-Ullrich JE, Mosher DF. 2006; Function-blocking antithrombospondin-1 monoclonal antibodies. J Thromb Haemost. 4:459-468. [PubMed: 16420580]

38. Annis DS, Gunderson KA, Mosher DF. 2007; Immunochemical analysis of the structure of the signature domains of thrombospondin-1 and thrombospondin-2 in low calcium concentrations. $\mathbf{J}$ Biol Chem. 282:27067-27075. [PubMed: 17620335]

39. Misenheimer TM, Mosher DF. 2005; Biophysical characterization of the signature domains of thrombospondin-4 and thrombospondin-2. J Biol Chem. 280:41229-41235. [PubMed: 16246837]

40. Stenina OI, Ustinov V, Krukovets I, Marinic T, Topol EJ, Plow EF. 2005; Polymorphisms A387P in thrombospondin-4 and N700S in thrombospondin-1 perturb calcium binding sites. FASEB J. 19:1893-1895. [PubMed: 16148025]

41. Wessel J, Topol EJ, Ji M, Meyer J, McCarthy JJ. 2004; Replication of the association between the thrombospondin-4 A387P polymorphism and myocardial infarction. Am Heart J. 147:905-909. [PubMed: 15131549]

42. McCarthy JJ, Parker A, Salem R, Moliterno DJ, Wang Q, Plow EF, Rao S, Shen G, Rogers WJ, Newby LK, Cannata R, Glatt K, Topol EJ. 2004; Large scale association analysis for identification of genes underlying premature coronary heart disease: cumulative perspective from analysis of 111 candidate genes. J Med Genet. 41:334-341. [PubMed: 15121769]

43. Wilsgaard T, Mathiesen EB, Patwardhan A, Rowe MW, Schirmer H, Lochen ML, Sudduth-Klinger J, Hamren S, Bonaa KH, Njolstad I. 2015; Clinically significant novel biomarkers for prediction of first ever myocardial infarction: the Tromso Study. Circ Cardiovasc Genet. 8:363-371. [PubMed: 25613532] 
44. Topol EJ, McCarthy J, Gabriel S, Moliterno DJ, Rogers WJ, Newby LK, Freedman M, Metivier J, Cannata R, O’Donnell CJ, Kottke-Marchant K, Murugesan G, Plow EF, Stenina O, Daley GQ. 2001; Single nucleotide polymorphisms in multiple novel thrombospondin genes may be associated with familial premature myocardial infarction. Circulation. 104:2641-2644. [PubMed: 11723011]

45. Yamada Y, Izawa H, Ichihara S, Takatsu F, Ishihara H, Hirayama H, Sone T, Tanaka M, Yokota M. 2002; Prediction of the risk of myocardial infarction from polymorphisms in candidate genes. $\mathrm{N}$ Engl J Med. 347:1916-1923. [PubMed: 12477941]

46. Kato T, Y A, Murase Y, Hirashiki A, Noda A, Yamada Y. 2003; Specific gene polymorphisms could be risk factors for coronary artery disease in individuals with or without hypertention. Circulation (Suppl). 108:IV-712.

47. Cui J, Randell E, Renouf J, Sun G, Han FY, Younghusband B, Xie YG. 2004; Gender dependent association of thrombospondin-4 A387P polymorphism with myocardial infarction. Arterioscler Thromb Vasc Biol. 24:e183-184. [PubMed: 15528485]

48. Cui J, Randell E, Renouf J, Sun G, Green R, Han FY, Xie YG. 2006; Thrombospondin-4 1186G>C (A387P) is a sex-dependent risk factor for myocardial infarction: a large replication study with increased sample size from the same population. Am Heart J. 152:543-545. e541-545. [PubMed: 16923428]

49. Frolova EG, Pluskota E, Krukovets I, Burke T, Drumm C, Smith JD, Blech L, Febbraio M, Bornstein P, Plow EF, Stenina OI. 2010; Thrombospondin-4 regulates vascular inflammation and atherogenesis. Circ Res. 107:1313-1325. [PubMed: 20884877]

50. Pluskota E, Stenina OI, Krukovets I, Szpak D, Topol EJ, Plow EF. 2005; Mechanism and effect of thrombospondin-4 polymorphisms on neutrophil function. Blood. 106:3970-3978. [PubMed: 16099885]

51. Crosby ND, Zaucke F, Kras JV, Dong L, Luo ZD, Winkelstein BA. 2015; Thrombospondin-4 and excitatory synaptogenesis promote spinal sensitization after painful mechanical joint injury. Exp Neurol. 264:111-120. [PubMed: 25483397]

52. Eroglu C, Allen NJ, Susman MW, O'Rourke NA, Park CY, Ozkan E, Chakraborty C, Mulinyawe SB, Annis DS, Huberman AD, Green EM, Lawler J, Dolmetsch R, Garcia KC, Smith SJ, Luo ZD, Rosenthal A, Mosher DF, Barres BA. 2009; Gabapentin receptor alpha2delta-1 is a neuronal thrombospondin receptor responsible for excitatory CNS synaptogenesis. Cell. 139:380-392. [PubMed: 19818485]

53. Pan B, Guo Y, Wu HE, Park J, Trinh VN, Luo ZD, Hogan QH. 2016; Thrombospondin-4 divergently regulates voltage-gated $\mathrm{Ca} 2+$ channel subtypes in sensory neurons after nerve injury. Pain. 157:2068-2080. [PubMed: 27168360]

54. Park J, Yu YP, Zhou CY, Li KW, Wang D, Chang E, Kim DS, Vo B, Zhang X, Gong N, Sharp K, Steward O, Vitko I, Perez-Reyes E, Eroglu C, Barres B, Zaucke F, Feng G, Luo ZD. 2016; Central Mechanisms Mediating Thrombospondin-4-induced Pain States. J Biol Chem. 291:13335-13348. [PubMed: 27129212]

55. Bentley AA, Adams JC. 2010; The evolution of thrombospondins and their ligand-binding activities. Mol Biol Evol. 27:2187-2197. [PubMed: 20427418]

56. Urry LA, Whittaker CA, Duquette M, Lawler J, DeSimone DW. 1998; Thrombospondins in early Xenopus embryos: dynamic patterns of expression suggest diverse roles in nervous system, notochord, and muscle development. Dev Dyn. 211:390-407. [PubMed: 9566958]

57. Lawler J, Duquette M, Whittaker CA, Adams JC, McHenry K, DeSimone DW. 1993; Identification and characterization of thrombospondin- 4 , a new member of the thrombospondin gene family. $\mathrm{J}$ Cell Biol. 120:1059-1067. [PubMed: 8432726]

58. Tucker RP, Adams JC, Lawler J. 1995; Thrombospondin-4 is expressed by early osteogenic tissues in the chick embryo. Dev Dyn. 203:477-490. [PubMed: 7496039]

59. Kasprick DS, Kish PE, Junttila TL, Ward LA, Bohnsack BL, Kahana A. 2011; Microanatomy of adult zebrafish extraocular muscles. PLoS One. 6:e27095. [PubMed: 22132088]

60. Schlotzer-Schrehardt U, Dietrich T, Saito K, Sorokin L, Sasaki T, Paulsson M, Kruse FE. 2007; Characterization of extracellular matrix components in the limbal epithelial stem cell compartment. Exp Eye Res. 85:845-860. [PubMed: 17927980] 
61. Hauser N, Paulsson M, Kale AA, DiCesare PE. 1995; Tendon extracellular matrix contains pentameric thrombospondin-4 (TSP-4). FEBS Lett. 368:307-310. [PubMed: 7628627]

62. Jelinsky SA, Archambault J, Li L, Seeherman H. 2010; Tendon-selective genes identified from rat and human musculoskeletal tissues. J Orthop Res. 28:289-297. [PubMed: 19780194]

63. Little D, Thompson JW, Dubois LG, Ruch DS, Moseley MA, Guilak F. 2014; Proteomic differences between male and female anterior cruciate ligament and patellar tendon. PLoS One. 9:e96526. [PubMed: 24818782]

64. Williamson KA, Lee KJ, Humphreys WJ, Comerford EJ, Clegg PD, Canty-Laird EG. 2015; Restricted differentiation potential of progenitor cell populations obtained from the equine superficial digital flexor tendon (SDFT). J Orthop Res. 33:849-858. [PubMed: 25877997]

65. Barsby T, Bavin EP, Guest DJ. 2014; Three-dimensional culture and transforming growth factor beta3 synergistically promote tenogenic differentiation of equine embryo-derived stem cells. Tissue Eng Part A. 20:2604-2613. [PubMed: 24628376]

66. Adams JC, Monk R, Taylor AL, Ozbek S, Fascetti N, Baumgartner S, Engel J. 2003; Characterisation of Drosophila thrombospondin defines an early origin of pentameric thrombospondins. J Mol Biol. 328:479-494. [PubMed: 12691755]

67. Subramanian A, Schilling TF. 2014; Thrombospondin-4 controls matrix assembly during development and repair of myotendinous junctions. Elife. 3

68. Whited JL, Lehoczky JA, Austin CA, Tabin CJ. 2011; Dynamic expression of two thrombospondins during axolotl limb regeneration. Dev Dyn. 240:1249-1258. [PubMed: 21360624]

69. Arber S, Caroni P. 1995; Thrombospondin-4, an extracellular matrix protein expressed in the developing and adult nervous system promotes neurite outgrowth. J Cell Biol. 131:1083-1094. [PubMed: 7490284]

70. Dunkle ET, Zaucke F, Clegg DO. 2007; Thrombospondin-4 and matrix three-dimensionality in axon outgrowth and adhesion in the developing retina. Exp Eye Res. 84:707-717. [PubMed: 17320079]

71. Si Z, Palkama A, Gebhardt BM, Velasquez D, Galeano MJ, Beuerman RW. 2003; Distribution of thrombospondin-4 in the bovine eye. Curr Eye Res. 27:165-173. [PubMed: 14562182]

72. Carron JA, Hiscott P, Hagan S, Sheridan CM, Magee R, Gallagher JA. 2000; Cultured human retinal pigment epithelial cells differentially express thrombospondin-1, -2, -3, and -4 . Int $\mathbf{J}$ Biochem Cell Biol. 32:1137-1142. [PubMed: 11137453]

73. Stenina OI, Desai SY, Krukovets I, Kight K, Janigro D, Topol EJ, Plow EF. 2003; Thrombospondin-4 and its variants: expression and differential effects on endothelial cells. Circulation. 108:1514-1519. [PubMed: 12952849]

74. Stenina-Adognravi O. 2014; Invoking the power of thrombospondins: regulation of thrombospondins expression. Matrix Biol. 37:69-82. [PubMed: 24582666]

75. Cho JY, Lim JY, Cheong JH, Park YY, Yoon SL, Kim SM, Kim SB, Kim H, Hong SW, Park YN, Noh SH, Park ES, Chu IS, Hong WK, Ajani JA, Lee JS. 2011; Gene expression signature-based prognostic risk score in gastric cancer. Clin Cancer Res. 17:1850-1857. [PubMed: 21447720]

76. D’Errico M, de Rinaldis E, Blasi MF, Viti V, Falchetti M, Calcagnile A, Sera F, Saieva C, Ottini L, Palli D, Palombo F, Giuliani A, Dogliotti E. 2009; Genome-wide expression profile of sporadic gastric cancers with microsatellite instability. Eur J Cancer. 45:461-469.

77. Singh D, Febbo PG, Ross K, Jackson DG, Manola J, Ladd C, Tamayo P, Renshaw AA, D'Amico AV, Richie JP, Lander ES, Loda M, Kantoff PW, Golub TR, Sellers WR. 2002; Gene expression correlates of clinical prostate cancer behavior. Cancer Cell. 1:203-209. [PubMed: 12086878]

78. Ma XJ, Wang Z, Ryan PD, Isakoff SJ, Barmettler A, Fuller A, Muir B, Mohapatra G, Salunga R, Tuggle JT, Tran Y, Tran D, Tassin A, Amon P, Wang W, Enright E, Stecker K, Estepa-Sabal E, Smith B, Younger J, Balis U, Michaelson J, Bhan A, Habin K, Baer TM, Brugge J, Haber DA, Erlander MG, Sgroi DC. 2004; A two-gene expression ratio predicts clinical outcome in breast cancer patients treated with tamoxifen. Cancer Cell. 5:607-616. [PubMed: 15193263]

79. Curtis C, Shah SP, Chin SF, Turashvili G, Rueda OM, Dunning MJ, Speed D, Lynch AG, Samarajiwa S, Yuan Y, Graf S, Ha G, Haffari G, Bashashati A, Russell R, McKinney S, Langerod A, Green A, Provenzano E, Wishart G, Pinder S, Watson P, Markowetz F, Murphy L, Ellis I, 
Purushotham A, Borresen-Dale AL, Brenton JD, Tavare S, Caldas C, Aparicio S. 2012; The genomic and transcriptomic architecture of 2,000 breast tumours reveals novel subgroups. Nature. 486:346-352. [PubMed: 22522925]

80. Lu X, Wang ZC, Iglehart JD, Zhang X, Richardson AL. 2008; Predicting features of breast cancer with gene expression patterns. Breast Cancer Res Treat. 108:191-201. [PubMed: 18297396]

81. Tan FL, Moravec CS, Li J, Apperson-Hansen C, McCarthy PM, Young JB, Bond M. 2002; The gene expression fingerprint of human heart failure. Proc Natl Acad Sci U S A. 99:11387-11392. [PubMed: 12177426]

82. Kim DJ, Christofidou ED, Keene DR, Hassan Milde M, Adams JC. 2015; Intermolecular interactions of thrombospondins drive their accumulation in extracellular matrix. Mol Biol Cell. 26:2640-2654. [PubMed: 25995382]

83. Bornstein P, Kyriakides TR, Yang Z, Armstrong LC, Birk DE. 2000; Thrombospondin 2 modulates collagen fibrillogenesis and angiogenesis. J Investig Dermatol Symp Proc. 5:61-66.

84. Kyriakides TR, Zhu YH, Smith LT, Bain SD, Yang Z, Lin MT, Danielson KG, Iozzo RV, LaMarca M, McKinney CE, Ginns EI, Bornstein P. 1998; Mice that lack thrombospondin 2 display connective tissue abnormalities that are associated with disordered collagen fibrillogenesis, an increased vascular density, and a bleeding diathesis. J Cell Biol. 140:419-430. [PubMed: 9442117]

85. Narouz-Ott L, Maurer P, Nitsche DP, Smyth N, Paulsson M. 2000; Thrombospondin-4 binds specifically to both collagenous and non-collagenous extracellular matrix proteins via its Cterminal domains. J Biol Chem. 275:37110-37117. [PubMed: 10956668]

86. Sodersten F, Ekman S, Niehoff A, Zaucke F, Heinegard D, Hultenby K. 2007; Ultrastructural immunolocalization of cartilage oligomeric matrix protein, thrombospondin-4, and collagen fibril size in rodent achilles tendon in relation to exercise. Connect Tissue Res. 48:254-262. [PubMed: 17882701]

87. Islam A, Younesi M, Mbimba T, Akkus O. 2016; Collagen Substrate Stiffness Anisotropy Affects Cellular Elongation, Nuclear Shape, and Stem Cell Fate toward Anisotropic Tissue Lineage. Adv Healthc Mater. 5:2237-2247. [PubMed: 27377355]

88. Berasi SP, Varadarajan U, Archambault J, Cain M, Souza TA, Abouzeid A, Li J, Brown CT, Dorner AJ, Seeherman HJ, Jelinsky SA. 2011; Divergent activities of osteogenic BMP2, and tenogenic BMP12 and BMP13 independent of receptor binding affinities. Growth Factors. 29:128-139. [PubMed: 21702718]

89. Paddock HN, Schultz GS, Baker HV, Varela JC, Beierle EA, Moldawer LL, Mozingo DW. 2003; Analysis of gene expression patterns in human postburn hypertrophic scars. J Burn Care Rehabil. 24:371-377. [PubMed: 14610421]

90. Vanhoutte D, Schips TG, Kwong JQ, Davis J, Tjondrokoesoemo A, Brody MJ, Sargent MA, Kanisicak O, Yi H, Gao QQ, Rabinowitz JE, Volk T, McNally EM, Molkentin JD. 2016; Thrombospondin expression in myofibers stabilizes muscle membranes. Elife. 5:e17589. [PubMed: 27669143]

91. Rainer PP, Hao S, Vanhoutte D, Lee DI, Koitabashi N, Molkentin JD, Kass DA. 2014; Cardiomyocyte-specific transforming growth factor beta suppression blocks neutrophil infiltration, augments multiple cytoprotective cascades, and reduces early mortality after myocardial infarction. Circ Res. 114:1246-1257. [PubMed: 24573206]

92. Subramanian A, Wayburn B, Bunch T, Volk T. 2007; Thrombospondin-mediated adhesion is essential for the formation of the myotendinous junction in Drosophila. Development. 134:12691278. [PubMed: 17314133]

93. Adams JC, Lawler J. 1994; Cell-type specific adhesive interactions of skeletal myoblasts with thrombospondin-1. Mol Biol Cell. 5:423-437. [PubMed: 7519904]

94. Kirk JA, Cingolani OH. 2016; Thrombospondins in the transition from myocardial infarction to heart failure. J Mol Cell Cardiol. 90:102-110. [PubMed: 26686988]

95. Lynch JM, Maillet M, Vanhoutte D, Schloemer A, Sargent MA, Blair NS, Lynch KA, Okada T, Aronow BJ, Osinska H, Prywes R, Lorenz JN, Mori K, Lawler J, Robbins J, Molkentin JD. 2012; A thrombospondin-dependent pathway for a protective ER stress response. Cell. 149:1257-1268. [PubMed: 22682248] 
96. Sawaki D, Hou L, Tomida S, Sun J, Zhan H, Aizawa K, Son BK, Kariya T, Takimoto E, Otsu K, Conway SJ, Manabe I, Komuro I, Friedman SL, Nagai R, Suzuki T. 2015; Modulation of cardiac fibrosis by Kruppel-like factor 6 through transcriptional control of thrombospondin 4 in cardiomyocytes. Cardiovasc Res. 107:420-430. [PubMed: 25987545]

97. Gabrielsen A, Lawler PR, Yongzhong W, Steinbruchel D, Blagoja D, Paulsson-Berne G, Kastrup J, Hansson GK. 2007; Gene expression signals involved in ischemic injury, extracellular matrix composition and fibrosis defined by global mRNA profiling of the human left ventricular myocardium. J Mol Cell Cardiol. 42:870-883. [PubMed: 17343875]

98. Duquette M, Nadler M, Okuhara D, Thompson J, Shuttleworth T, Lawler J. 2014; Members of the thrombospondin gene family bind stromal interaction molecule 1 and regulate calcium channel activity. Matrix Biol. 37:15-24. [PubMed: 24845346]

99. Stenina OI, Byzova TV, Adams JC, McCarthy JJ, Topol EJ, Plow EF. 2004; Coronary artery disease and the thrombospondin single nucleotide polymorphisms. Int J Biochem Cell Biol. 36:1013-1030. [PubMed: 15094117]

100. Volpert OV, Tolsma SS, Pellerin S, Feige JJ, Chen H, Mosher DF, Bouck N. 1995; Inhibition of angiogenesis by thrombospondin-2. Biochem Biophys Res Commun. 217:326-332. [PubMed: 8526929]

101. Schultz-Cherry S, Chen H, Mosher DF, Misenheimer TM, Krutzsch HC, Roberts DD, MurphyUllrich JE. 1995; Regulation of transforming growth factor-beta activation by discrete sequences of thrombospondin 1. J Biol Chem. 270:7304-7310. [PubMed: 7706271]

102. Schultz-Cherry S, Lawler J, Murphy-Ullrich JE. 1994; The type 1 repeats of thrombospondin 1 activate latent transforming growth factor-beta. J Biol Chem. 269:26783-26788. [PubMed: 7929414]

103. Flugel-Koch C, Ohlmann A, Fuchshofer R, Welge-Lussen U, Tamm ER. 2004; Thrombospondin-1 in the trabecular meshwork: localization in normal and glaucomatous eyes, and induction by TGF-beta1 and dexamethasone in vitro. Exp Eye Res. 79:649-663. [PubMed: 15500824]

104. Okamoto M, Ono M, Uchiumi T, Ueno H, Kohno K, Sugimachi K, Kuwano M. 2002; Upregulation of thrombospondin-1 gene by epidermal growth factor and transforming growth factor beta in human cancer cells-transcriptional activation and messenger RNA stabilization. Biochim Biophys Acta. 1574:24-34. [PubMed: 11955611]

105. Amy EM, Song S, Kutasovic JR, Reid LE, Valle JM, Vargas AC, Smart CE, Simpson PT. 2013; Thrombospondin-4 expression is activated during the stromal response to invasive breast cancer. Virchows Arch. 463:535-545. [PubMed: 23942617]

106. Korkola JE, DeVries S, Fridlyand J, Hwang ES, Estep AL, Chen YY, Chew KL, Dairkee SH, Jensen RM, Waldman FM. 2003; Differentiation of lobular versus ductal breast carcinomas by expression microarray analysis. Cancer Res. 63:7167-7175. [PubMed: 14612510]

107. Forster S, Gretschel S, Jons T, Yashiro M, Kemmner W. 2011; THBS4, a novel stromal molecule of diffuse-type gastric adenocarcinomas, identified by transcriptome-wide expression profiling. Mod Pathol. 24:1390-1403. [PubMed: 21701537]

108. Sugimura J, Yang XJ, Tretiakova MS, Takahashi M, Kort EJ, Fulton B, Fujioka T, Vogelzang NJ, Teh BT. 2004; Gene expression profiling of mesoblastic nephroma and Wilms tumorscomparison and clinical implications. Urology. 64:362-368. [PubMed: 15302496]

109. Liu J, Cheng G, Yang H, Deng X, Qin C, Hua L, Yin C. 2016; Reciprocal regulation of long noncoding RNAs THBS4003 and THBS4 control migration and invasion in prostate cancer cell lines. Mol Med Rep. 14:1451-1458. [PubMed: 27357608]

110. Su F, Zhao J, Qin S, Wang R, Li Y, Wang Q, Tan Y, Jin H, Zhu F, Ou Y, Cheng Z, Su W, Zhao F, Yang Y, Zhou Z, Zheng J, Li Y, Li Z, Wu Q. 2017; Over-expression of Thrombospondin 4 correlates with loss of miR-142 and contributes to migration and vascular invasion of advanced hepatocellular carcinoma. Oncotarget. 8:23277-23288. [PubMed: 28177895]

111. Margagliotti S, Clotman F, Pierreux CE, Beaudry JB, Jacquemin P, Rousseau GG, Lemaigre FP. 2007; The Onecut transcription factors HNF-6/OC-1 and OC-2 regulate early liver expansion by controlling hepatoblast migration. Dev Biol. 311:579-589. [PubMed: 17936262] 
112. Kondo Y, Shen L, Yan PS, Huang TH, Issa JP. 2004; Chromatin immunoprecipitation microarrays for identification of genes silenced by histone H3 lysine 9 methylation. Proc Natl Acad Sci U S A. 101:7398-7403. [PubMed: 15123805]

113. Greco SA, Chia J, Inglis KJ, Cozzi SJ, Ramsnes I, Buttenshaw RL, Spring KJ, Boyle GM, Worthley DL, Leggett BA, Whitehall VL. 2010; Thrombospondin-4 is a putative tumoursuppressor gene in colorectal cancer that exhibits age-related methylation. BMC Cancer. 10:494. [PubMed: 20846368]

114. van Doorn R, Zoutman WH, Dijkman R, de Menezes RX, Commandeur S, Mulder AA, van der Velden PA, Vermeer MH, Willemze R, Yan PS, Huang TH, Tensen CP. 2005; Epigenetic profiling of cutaneous T-cell lymphoma: promoter hypermethylation of multiple tumor suppressor genes including BCL7a, PTPRG, and p73. J Clin Oncol. 23:3886-3896. [PubMed: 15897551]

115. Risher WC, Eroglu C. 2012; Thrombospondins as key regulators of synaptogenesis in the central nervous system. Matrix Biol. 31:170-177. [PubMed: 22285841]

116. Christopherson KS, Ullian EM, Stokes CC, Mullowney CE, Hell JW, Agah A, Lawler J, Mosher DF, Bornstein P, Barres BA. 2005; Thrombospondins are astrocyte-secreted proteins that promote CNS synaptogenesis. Cell. 120:421-433. [PubMed: 15707899]

117. Yang HJ, Ma SP, Ju F, Zhang YP, Li ZC, Zhang BB, Lian JJ, Wang L, Cheng BF, Wang M, Feng ZW. 2016; Thrombospondin-4 Promotes Neuronal Differentiation of NG2 Cells via the ERK/ MAPK Pathway. J Mol Neurosci. 60:517-524. [PubMed: 27647309]

118. Benner EJ, Luciano D, Jo R, Abdi K, Paez-Gonzalez P, Sheng H, Warner DS, Liu C, Eroglu C, Kuo CT. 2013; Protective astrogenesis from the SVZ niche after injury is controlled by Notch modulator Thbs4. Nature. 497:369-373. [PubMed: 23615612]

119. Girard F, Eichenberger S, Celio MR. 2014; Thrombospondin 4 deficiency in mouse impairs neuronal migration in the early postnatal and adult brain. Mol Cell Neurosci. 61:176-186. [PubMed: 24983516]

120. Andersson D, Wilhelmsson U, Nilsson M, Kubista M, Stahlberg A, Pekna M, Pekny M. 2013; Plasticity response in the contralesional hemisphere after subtle neurotrauma: gene expression profiling after partial deafferentation of the hippocampus. PLoS One. 8:e70699. [PubMed: 23936241]

121. Kim DS, Li KW, Boroujerdi A, Peter Yu Y, Zhou CY, Deng P, Park J, Zhang X, Lee J, Corpe M, Sharp K, Steward O, Eroglu C, Barres B, Zaucke F, Xu ZC, Luo ZD. 2012; Thrombospondin-4 contributes to spinal sensitization and neuropathic pain states. J Neurosci. 32:8977-8987. [PubMed: 22745497]

122. Pan B, Yu H, Park J, Yu YP, Luo ZD, Hogan QH. 2015; Painful nerve injury upregulates thrombospondin-4 expression in dorsal root ganglia. J Neurosci Res. 93:443-453. [PubMed: 25327416]

123. Crosby ND, Winkelstein BA. 2016; Spinal Astrocytic Thrombospondin-4 Induced by Excitatory Neuronal Signaling Mediates Pain After Facet Capsule Injury. Ann Biomed Eng. 44:3215-3224. [PubMed: 27160673] 


\section{Highlights}

- Thrombospondin-4 (TSP-4) regulates ECM synthesis, composition, and organization

- $\quad$ TSP-4 regulates tissue and ECM remodeling in embryonic development and in adults after injury

- $\quad$ TSP-4 has intracellular functions in endoplasmic reticulum where it initiates stress-response signaling

- $\quad$ TSP-4 has functions distinct form other members of thrombospondin family members

- $\quad$ TSP-4 regulates remodeling of multiple tissues and organs including the heart, the nervous system, the skeletal muscle, the tendon, and cancers. 
A

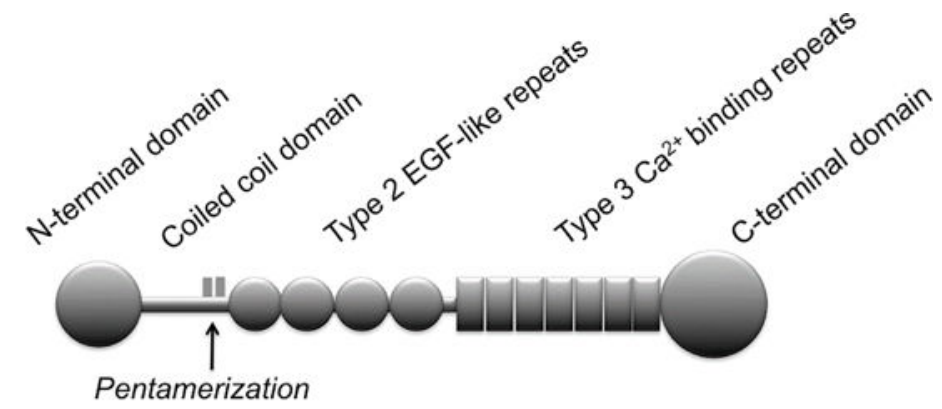

B
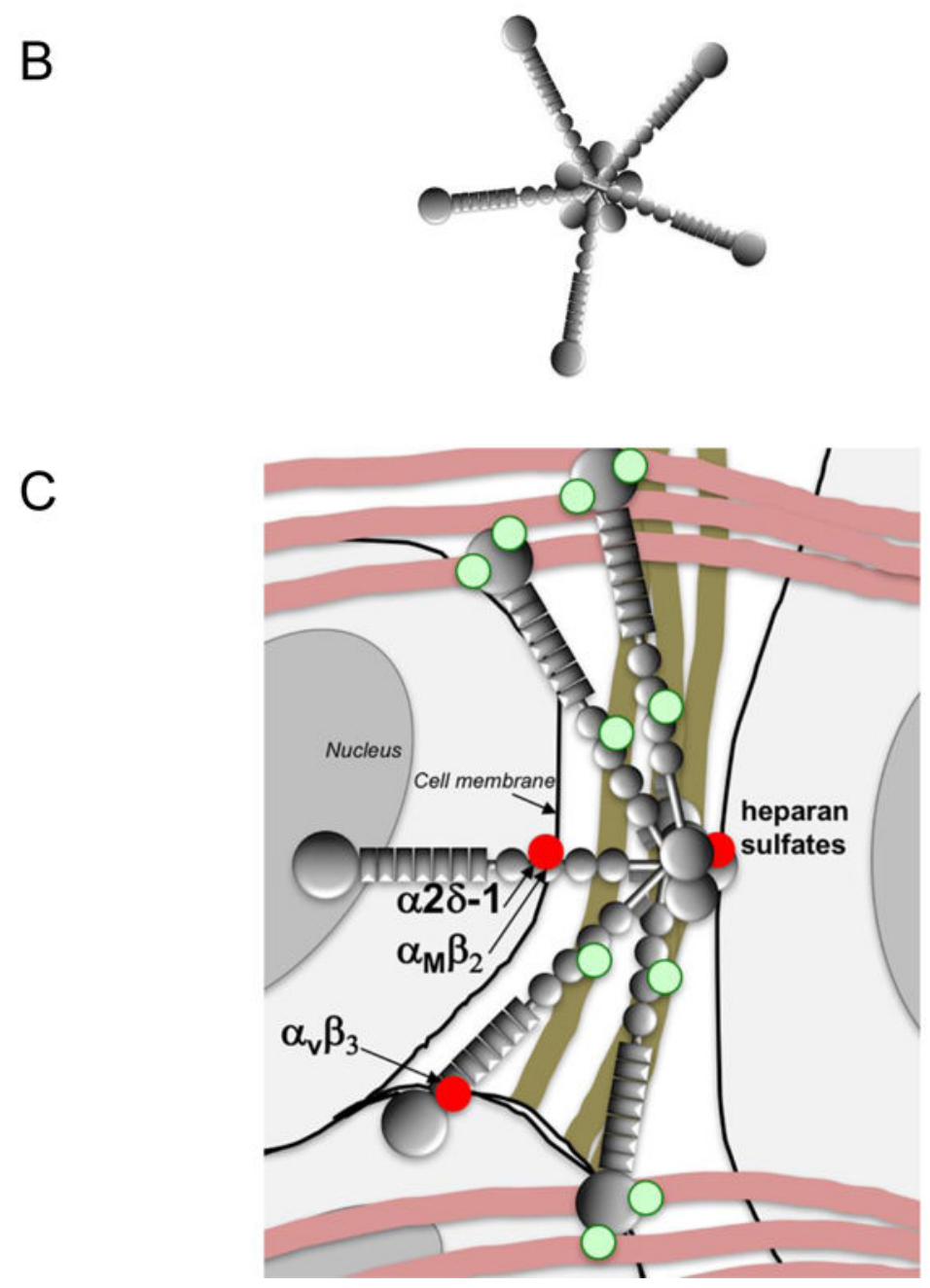

Figure 1. Domain structure of TSP-4 and its interaction with cells and ECM

A: Domains of a TSP-4 monomer; B: TSP-4 is a pentamer; C: The pentameric structure allows TSP-4 to engage in multiple interactions with cells and proteins in ECM through binding sites in heparin-binding N-terminal domain, EGF-like domains, and conserved Llectin C-terminal domain. Binding sites for the cellular receptors are marked with red dots (e.g., heparan sulfates, integrins $\alpha_{v} \beta_{3}$, and $a_{M} \beta_{2}$, gabapentin receptor $a_{2} \delta$-1); binding sites for ECM proteins are marked with green dots. There are both the ECM ligands binding the L-lectin domain (shown in pink), and ligands with binding sites in other domains of TSP-4, 
e.g., in EGF-like domains (shown in brown). Thus, a single molecule of TSP-4 can simultaneously engage multiple cellular receptors and ECM ligands and organize ECM and the interaction of the cells with ECM. 
Table 1

Functions of TSP-4

\begin{tabular}{|c|c|c|c|c|}
\hline Function & Location & Receptor & Signaling & References \\
\hline Promotes angiogenesis & $\begin{array}{l}\text { Tumor, Heart, Skin wound } \\
\text { Endothelial cells }\end{array}$ & $\begin{array}{l}a 2 \delta-1 \\
a_{2} \text {-integrin }\end{array}$ & & $(16-18)$ \\
\hline Mediates effects of TGF- $\beta$ & Tumor, Endothelial cells & & $\begin{array}{l}\text { TSP-4 is } \\
\text { upregulated by } \\
\text { TGF- } \beta \text { via } \\
\text { SMAD3; TSP-4 } \\
\text { increases levels of } \\
\text { TGF- } \beta \text { receptor } \\
\beta \text {-glycan }\end{array}$ & $(16,30)$ \\
\hline Suppresses production of ECM & Heart, Cultured fibrobalsts & & & $(18,30,31)$ \\
\hline Stimulates production of ECM & Skeletal muscle & & TGF- $\beta$ & $(30)$ \\
\hline Organizes ECM & $\begin{array}{l}\text { Muscle } \\
\text { Tendon }\end{array}$ & & & $(67,85,90,92)$ \\
\hline $\begin{array}{l}\text { Controls modifications of } \\
\text { Heparan Sulfates chains }\end{array}$ & $\begin{array}{l}\text { Skeletal muscle } \\
\text { Endothelial cells }\end{array}$ & & $\begin{array}{l}\text { Heparan sulfate 2- } \\
\text { O- } \\
\text { sulfotransferase } 1 \\
\text { and N-heparan } \\
\text { sulfate } \\
\text { sulfotransferase } 3\end{array}$ & $(30)$ \\
\hline $\begin{array}{l}\text { Regulates remodeling of } \\
\text { myocardium }\end{array}$ & Heart & & $\begin{array}{l}\text { Kruppel-like } \\
\text { factor } 6 \text { (Klf6) } \\
\text { upregulates } \\
\text { TSP-4 in } \\
\text { angiotensin II } \\
\text { infusion model of } \\
\text { cardiac } \\
\text { hypertrophy }\end{array}$ & $(18,30,31,96)$ \\
\hline $\begin{array}{l}\text { Regulation of adaptive cardiac } \\
\text { contractile response }\end{array}$ & Heart & & ERK1/2; Akt & $(31)$ \\
\hline Limb regeneration & Transitional matrix, axolotl & & & $(68)$ \\
\hline Organization of collagen fibers & Tendon & & & $(30)$ \\
\hline $\begin{array}{l}\text { Regulates skeletal muscle } \\
\text { integrity and metabolism }\end{array}$ & & & & $\begin{array}{l}(30,59,67,69,90, \\
92)\end{array}$ \\
\hline $\begin{array}{l}\text { Organization of myotendinous } \\
\text { and neuromuscular junction }\end{array}$ & Skeletal muscle & & & $(59,67,69,92)$ \\
\hline $\begin{array}{l}\text { Wound healing and scar } \\
\text { formation }\end{array}$ & & & & $(17,89)$ \\
\hline $\begin{array}{l}\text { Regulation of functions of stem } \\
\text { cells }\end{array}$ & $\begin{array}{l}\text { Eye (ocular surface } \\
\text { epithelia) }\end{array}$ & & & $(60)$ \\
\hline Promotes local inflammation & $\begin{array}{l}\text { Blood vessels Endothelial } \\
\text { cells }\end{array}$ & & & $(18)$ \\
\hline $\begin{array}{l}\text { Promotes atherogenesis and } \\
\text { CAD }\end{array}$ & & & & $(18,41-48)$ \\
\hline $\begin{array}{l}\text { Promotes adhesion, migration, } \\
\text { recruitment of leukocytes into } \\
\text { tissues, and pro-inflammatory } \\
\text { responses }\end{array}$ & & $a_{M} \beta_{2}$-integrin, $a_{V} \beta_{3}$-integrin, & P38 MAPK & $(49,50)$ \\
\hline Regulates cancer growth & $\begin{array}{l}\text { Gastric cancer; Breast } \\
\text { cancer; Liver cancer; } \\
\text { Colorectal cancer, Prostate } \\
\text { cancer }\end{array}$ & & & $\begin{array}{l}(16,17,75-80 \\
105-111,113)\end{array}$ \\
\hline $\begin{array}{l}\text { Promotes neurite outgrowth, } \\
\text { neuronal differentiation, and }\end{array}$ & Nervous system & Notch1 & & $(69,70,117-120)$ \\
\hline
\end{tabular}




\begin{tabular}{|c|c|c|c|c|}
\hline Function & Location & Receptor & Signaling & References \\
\hline \multicolumn{5}{|l|}{$\begin{array}{l}\text { post-injury recruitment of } \\
\text { neural stem cells }\end{array}$} \\
\hline Promotes formation of synapses & Nervous system & $a 2 \delta-1$ & & $(115,116)$ \\
\hline Nociception & Nervous system & $a 2 \delta 1$ & $\begin{array}{l}\text { Decreasing high- } \\
\text { voltage- activated } \\
\text { calcium current } \\
\text { and increasing } \\
\text { low-voltage- } \\
\text { activated calcium } \\
\text { current }\end{array}$ & $\begin{array}{l}(51,53,54,121- \\
123)\end{array}$ \\
\hline Activates ER stress response & ER of cardiomyocytes & $\begin{array}{l}\text { Activating transcription factor } \\
6 a(\text { Atf } 6 a)\end{array}$ & $\begin{array}{l}\text { Activating } \\
\text { transcription } \\
\text { factor } 6 a(\text { Atf6a) }\end{array}$ & (95) \\
\hline Regulates $\mathrm{Ca}^{2+}$ signaling & ER, variety of cells & STIM1 & $\begin{array}{l}\text { Calcium release } \\
\text { activated calcium } \\
\text { (CRAC) channel } \\
\text { and arachidonic } \\
\text { acid calcium } \\
\text { (ARC) channel }\end{array}$ & $(98)$ \\
\hline
\end{tabular}

